\title{
Effects of abiotic variables on the distribution of fish assemblages in streams with different anthropogenic activities in southern Brazil
}

\author{
Vanessa Salete Daga ${ }^{1}$, Éder André Gubiani ${ }^{1,2}$, Almir Manoel Cunico ${ }^{3}$ and Gilmar \\ Baumgartner ${ }^{1,2}$
}

Studies on fish assemblages in streams point out, that understanding the relationship between species and their environment is crucial for conservation. The present study aimed at evaluating the effects of changes in abiotic variables on the composition and structure of fish assemblages in Neotropical urban streams from southern Brazil with different levels of urbanization. The composition and structure of fish assemblages showed significant differences along the urbanization gradient observed in the streams. Tolerant and non-native species were found in more urbanized sites. A matrix correlation revealed a relationship between abiotic variables and the spatial pattern of structure and composition of fish assemblages. Abiotic variables, such as total phosphorus, dissolved oxygen, and conductivity, determined the distribution of fish assemblages. Streams without urban influence exhibited intrinsically low species richness, suggesting that they are highly susceptible to species loss and diversity reduction. Thus, changes in water quality or hydrological conditions induced by urbanization may intensify these impacts.

Estudos sobre as assembleias de peixes em riachos têm enfatizado que a compreensão da relação entre as espécies e seu ambiente é crucial para a conservação das espécies. O objetivo deste estudo foi avaliar os efeitos de alterações nas variáveis abióticas sobre a composição e estrutura das assembleias de peixes em riachos urbanos com diferentes percentuais de urbanização no Brasil. A composição e estrutura das assembleias de peixes mostraram diferenças significativas ao longo do gradiente de urbanização dos riachos. Espécies tolerantes e não-nativas foram encontradas em locais mais urbanizados. A análise de correlação de matrizes indicou uma relação entre as variáveis abióticas e do arranjo espacial da estrutura e composição nas assembleias de peixes. Variáveis abióticas, tais como fósforo total, oxigênio dissolvido e condutividade, determinaram a distribuição das assembleias de peixes. Riachos sem influência urbana exibem naturalmente baixa riqueza específica, sugerindo ser suscetíveis à perda de espécies e redução da diversidade. Assim, mudanças induzidas pela urbanização na qualidade da água ou no regime hidrológico podem exacerbar esses impactos.

Key words: Abiotic variables, Anthropogenic effects, Ichthyofauna, Urbanization.

\section{Introduction}

Understanding spatial and temporal changes in population size and distribution, as well as mechanisms and processes responsible for these changes, is an important goal of community studies (Ornellas \& Coutinho, 1998). The current rate of destruction, alteration, and fragmentation of natural habitats as a result of human activities led to an alarming loss of global biodiversity (Schindler, 2007). The fast growth of urban centers resulted in habitat degradation, with marked effects on aquatic ecosystems (Lee, 2000). Biotic and abiotic factors affect the distribution and abundance of fish, in both pristine and impacted streams (Schlosser, 1991; Paul \& Meyer, 2001).
Abiotic factors, such as integrity of the riparian vegetation, spatial differences in habitat diversity and structural complexity (e.g., wood debris, macrophytes, backwaters, and rapids), morphometric characteristics (depth, water velocity, and substrate), spatial differences in physical and chemical variables (water temperature, electric conductivity, nitrogen and phosphorus concentrations, and $\mathrm{pH}$ ), and biotic interactions (competition and predation; Schlosser, 1990; Infante et al., 2009; Pool et al., 2010) affect the distribution of species in pristine streams. In urban streams, changes in the landscape greatly affect species distribution (Alberti et al., 2007; Fialho et al., 2008; Maloney \& Weller, 2010; Alexandre et al., 2010; Cunico et al., 2012). Urban growth through

${ }^{1}$ Universidade Estadual do Oeste do Paraná, Programa de Pós-graduação em Recursos Pesqueiros e Engenharia de Pesca. Rua da Faculdade, 645, Jardim Santa Maria, 85903-000 Toledo, Paraná, Brazil. vanedaga@yahoo.com.br (VSD)

${ }^{2}$ Universidade Estadual do Oeste do Paraná, Grupo de Estudos em Recursos Pesqueiros e Limnologia (Gerpel). Rua da Faculdade, 645, Jardim Santa Maria, 85903-000 Toledo, Paraná, Brazil. egubiani@yahoo.com.br (EAG), gilmar_baum@yahoo.com.br (GB)

${ }^{3}$ Universidade Federal do Paraná, Laboratório de Ecologia, Pesca e Ictiologia, Câmpus Palotina. Rua Pioneiro, 2153, Jardim Dallas, 85950-000 Palotina, Paraná, Brazil. almircunico@ufpr.br (AMC) 
construction and deforestation has increased surface runoff due to soil sealing (Paul \& Meyer, 2001). These factors may increase sediment load and discharge, altering channel geometry (Montgomery \& Buffington, 1998).

Despite a significant increase in studies on the ichthyofauna of tropical streams in the past few years, temperate areas are still better known (Winemiller et al., 2008). Fish diversity estimates in Brazilian inland waters, mainly in urban streams, are still imprecise due to the lack of comprehensive inventories (Agostinho et al., 2008). First-order streams are abundant and unique components of the river network: they have high biological diversity and are important for the maintenance of the biotic integrity of entire ecosystems (Meyer et al., 2007). Studies assessing responses of fish species to urbanization in headwater streams are scarce in the Neotropical region (Cunico et al., 2006), making it difficult to develop strategies for impact mitigation and conservation of the fish fauna.

Hence, the present study aimed at evaluating the relationships between abiotic variables and the distribution of fish assemblages in some Neotropical streams. Our main objective was to understand how changes in abiotic variables affect the composition and structure of fish assemblages in streams with different anthropogenic activities.

\section{Material and Methods}

\section{Study area}

Data were collected in nine sites of three first-order streams (sensu Strahler, 1957; Fig. 1, Table 1), in the São Francisco Verdadeiro River sub-basin. The streams are located within the urban area in the city of Toledo, State of Paraná, southern Brazil, and belong to the Paraná III basin (Suderhsa, 2009), which is composed of several sub-basins, including the São Francisco Verdadeiro River sub-basin. This sub-basin, formed by several rivers and streams, became highly-impacted due to human activities, such as agriculture and urbanization (Gubiani et al., 2010). Corn and soybean crops, as well as livestock such as pigs, cattle, and fish, are the main land use regimes in the area. Fish farming occurs exclusively in ponds, in which Oreochromis niloticus is the main species.

The headwaters of Panambi Stream are located within the urban area in the city of Toledo (Fig. 1); the margins are fully occupied by residences, and receive domestic and industrial effluents, such as sewage, oil, and grease. The headwaters of Pinheirinho Stream are located outside the urban area in the city of Toledo (Fig. 1) and are affected by agriculture (\% rural use $=51.58)$; in its middle portion the stream is impacted also by residences. Jacutinga Stream is less impacted by residences, but it is affected by aquaculture and agriculture (\% rural use $=75.42$; Fig. 1$)$.

\section{Sampling}

We selected three sites (headwaters, middle, and mouth; Table 1) in each of the three streams studied, and samples were collected bimonthly from December 2007 to December 2008 along the streams (Fig. 1). Fish were collected with permission of IAP (Instituto Ambiental do Paraná, permit n 755/2008). The length of the sampling transect in each site was standardized in $40 \mathrm{~m}$. This length represents approximately 20 times the channel width and comprises at least one complete meander wavelength. This approach assures that all habitat types are represented within each transect (Hauer \& Lamberti, 2007). Fish were caught with an electrofishing equipment powered by a portable generator (HONDA, $2.5 \mathrm{~kW}, 220 \mathrm{~V}, 3-4$ A) connected to a DC transformer and two electrified net rings (anode and cathode). Output voltage varied from 400 to $600 \mathrm{~V}$. Each transect was sampled three times from downstream to upstream by four people in a constant fishing effort of $30 \mathrm{~min}$ each time, following Esteves \& Lobón-Cerviá (2001). The sampling site was blocked by a net $(0.5 \mathrm{~cm}$ of mesh size) to prevent fish from getting in and out.

After being captured, fish were killed with benzocaine hydrochloride (250 mg. ${ }^{-1}$ ) following Avma (2001), fixed in plastics bags containing formaldehyde $4 \%$, and stored in polyethylene containers. In the laboratory fish were identified to the species and counted. Voucher specimens were deposited in the fish collection of Nupelia (Núcleo de Pesquisas em Limnologia, Ictiologia e Aquicultura), Universidade Estadual de Maringá, Brazil, and information is available at: www.nupelia.uem.br/colecao.

Physical variables, such as depth and width (m), water velocity $\left(\mathrm{m} . \mathrm{s}^{-1}\right)$, discharge $\left(\mathrm{m}^{3} \cdot \mathrm{s}^{-1}\right)$, water temperature $\left({ }^{\circ} \mathrm{C}\right)$, and substrate (pipette method; Embrapa, 1997), were measured following Matthews (1998) and Hauer \& Lamberti (2007). Chemical variables, such as $\mathrm{pH}$, electric conductivity $\left(\mu \mathrm{S} . \mathrm{cm}^{-1}\right)$, dissolved oxygen (mg. $\left.\mathrm{l}^{-1}\right)$, total nitrogen $\left(\mathrm{N}, \mu \mathrm{g} . \mathrm{l}^{-1}\right)$, total phosphorus $\left(\mathrm{P}, \mu \mathrm{g} . \mathrm{l}^{-1}\right)$, and chemical and biochemical oxygen demand (COD, BOD; mg.l $^{-1} \mathrm{O}_{2}$ ), followed Apha (2005) and were measured in the limnology laboratory of Universidade Estadual do Oeste do Paraná - Campus Toledo.

The level of urbanization (given as a percentage) was measured using high-resolution satellite images in Spring 4.3.2 (Camara et al., 1996). The drainage area was measured using overlapped images and altimetric charts. The percentage of urbanization was calculated by overlapping micro-basin and urban limits (land use and infrastructure). Impermeable surface areas were measured using the vectorial edition tool in Spring 4.3.2. These variables were used to describe environmental conditions and their potential effects on the structure of fish assemblages.

\section{Data analysis}

Composition and structure of fish assemblages. Species identification followed Graça \& Pavanelli (2007), except for Trichomycterus sp. and Ancistrus sp. Species classification followed Eschmeyer (2012) for higher taxa and Reis et al. (2003) for Neotropical families. Fish abundance was measured as density (individuals.hectare ${ }^{-1}$ ). We applied a non-metric multidimensional scaling analysis (NMDS) to summarize the composition and structure of fish assemblages using Sorensen distances and following the general NMDS procedure proposed by McCune \& Grace (2002). Random 


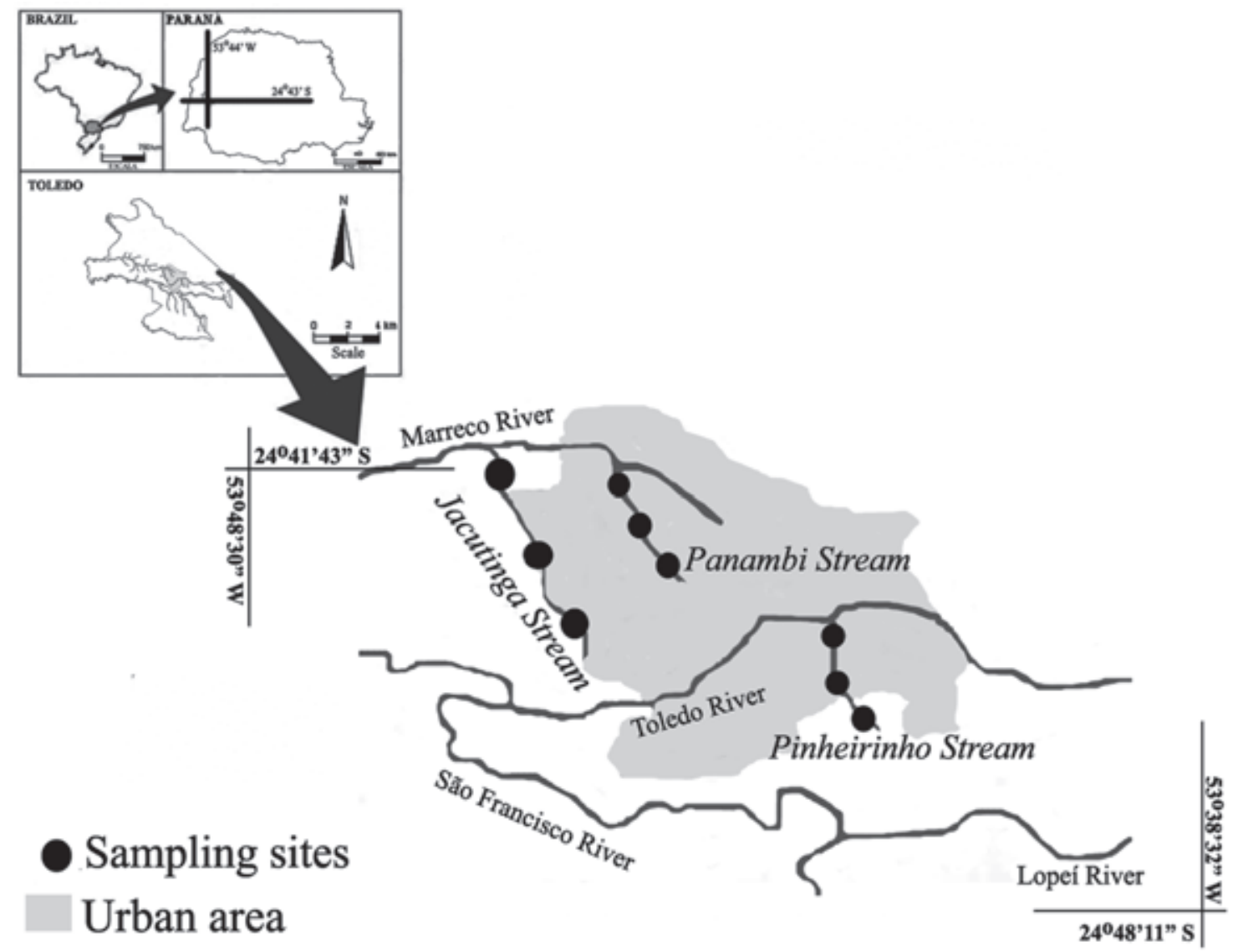

Fig. 1. Sampling sites in three streams located in the city of Toledo, State of Paraná, southern Brazil.

start configurations, with 100 runs of real data and a stability criterion of $\leq 0.005$ standard deviations of stress were used. This analysis was carried out using the density matrix of each sampling site.

To test for differences in composition and structure of the fish assemblage among sites summarized by the NMDS, we used a multi-response permutation procedure (MRPP) with different urbanization percentages (Table 1; Zimmerman et al., 1985). The null hypothesis was that the composition and structure of the fish assemblage did not differ among sites; we used a Monte Carlo procedure with 10,000 permutations to estimate the significance.

The indicator value method (IndVal; Dufrêne \& Legendre, 1997) was used to detect how differently each species is distributed among sites. The indicator value of a species varies from 0 to 100 , and it reaches its maximum value when all individuals of a species occur in all sites within a single NMDS group. We tested for the significance of the indicator value of each species with a Monte Carlo procedure with 1,000 permutations.

Table 1. Stretches sampled in three streams located in urban area in the city of Toledo, State of Paraná, southern Brazil, as well as their geographic coordinates and level of urbanization.

\begin{tabular}{|c|c|c|c|c|c|c|}
\hline \multirow[b]{2}{*}{ Stream } & \multirow[b]{2}{*}{ Stretch } & \multicolumn{2}{|c|}{ Geographic coordinates } & \multirow{2}{*}{ Altitude (m asl) } & \multirow{2}{*}{ Length stream $(\mathrm{km})$} & \multirow{2}{*}{ \% Urbanization } \\
\hline & & $\mathrm{W}$ & $\mathrm{S}$ & & & \\
\hline \multirow{3}{*}{ Jacutinga } & Headwaters & $53^{\circ} 46^{\prime} 22^{\prime \prime}$ & $24^{\circ} 43^{\prime} 15^{\prime \prime}$ & 551 & \multirow{3}{*}{4.19} & \multirow{3}{*}{24.58} \\
\hline & Middle & $53^{\circ} 46^{\prime} 21^{\prime \prime}$ & $24^{\circ} 42^{\prime} 56^{\prime \prime}$ & 542 & & \\
\hline & Mouth & $53^{\circ} 46^{\prime} 11^{\prime \prime}$ & $24^{\circ} 41^{\prime} 58^{\prime \prime}$ & 523 & & \\
\hline \multirow{3}{*}{ Pinheirinho } & Headwaters & $53^{\circ} 42^{\prime} 33^{\prime \prime}$ & $24^{\circ} 45^{\prime} 23^{\prime \prime}$ & 543 & \multirow{3}{*}{2.85} & \multirow{3}{*}{48.42} \\
\hline & Middle & $53^{\circ} 42^{\prime} 48^{\prime \prime}$ & $24^{\circ} 44^{\prime} 46^{\prime \prime}$ & 510 & & \\
\hline & Mouth & $53^{\circ} 42^{\prime} 55^{\prime \prime}$ & $24^{\circ} 44^{\prime} 05^{\prime \prime}$ & 485 & & \\
\hline \multirow{3}{*}{ Panambi } & Headwaters & $53^{\circ} 44^{\prime} 53^{\prime \prime}$ & $24^{\circ} 43^{\prime} 04^{\prime \prime}$ & 547 & \multirow{3}{*}{3.31} & \multirow{3}{*}{53.26} \\
\hline & Middle & $53^{\circ} 45^{\prime} 08^{\prime \prime}$ & $24^{\circ} 42^{\prime} 25^{\prime \prime}$ & 536 & & \\
\hline & Mouth & $53^{\circ} 45^{\prime} 25^{\prime \prime}$ & $24^{\circ} 41^{\prime} 55^{\prime \prime}$ & 526 & & \\
\hline
\end{tabular}


Abiotic variables and their influence on fish assemblages.

Abiotic variables were divided into two matrices: one with physical and chemical variables (electric conductivity, $\mathrm{pH}$, water temperature, dissolved oxygen, total nitrogen, total phosphorus, BOD, and COD), and the other with morphometric variables (width, water velocity, discharge, depth, clay, silt, and sand). A multivariate analysis of variance (MANOVA; Scheiner \& Gurevitch, 1993) was used to test for differences among abiotic variables. We tested for normality with the Shapiro-Wilk test and for homoscedasticity with the Levene test. Whenever the MANOVA was significant, it was possible to use a oneway ANOVA for each variable separately (Johnson, 1998). Hence, we also calculated one-way ANOVAs (factor: streams - Jacutinga, Pinheirinho, and Panambi). The main ANOVA model, controlling for temporal variability among blocks, was not significant (blocks: months). Whenever the one-way ANOVA was significant and its assumptions were met, we used a Tukey test to identify the categories that differed from each other. When none of the assumptions of ANOVA were met, we used the rank transformation method (Quinn \& Keough, 2002) and then applied a parametric ANOVA to ranked data (Conover \& Iman, 1981); homoscedasticity was also tested in the ranked data. Furthermore, when the assumptions of ANOVA were not met, we also used a non-parametric Kruskal-Wallis test (Zar, 1999; Quinn \& Keough, 2002).

Matrices were summarized using a principal components analysis (PCA). As the variables showed strong linear bivariate relationships, the PCA was chosen as the most appropriate ordination technique to summarize the variation. To determine which principal components would be retained for interpretation we used the broken-stick model (Jackson, 1993). According to this model, only the axes with eigenvalues higher than the eigenvalues generated with the broken-stick model should be interpreted.

The association between multivariate summaries of abiotic variables and composition and structure of fish assemblages was tested using a procrustean superimposition approach (Gower, 1971; Jackson, 1995; Peres-Neto \& Jackson, 2001). In this analysis, two data matrices are compared using a rotational-fit algorithm that minimizes the sum of squared residuals between them $\left(\mathrm{m}^{2}\right.$ statistic; Gower, 1975; Rohlf \& Slice, 1990). The resultant lower value of $\mathrm{m}^{2}$ is a goodness-of-fit statistic that describes the degree of association between the two matrices. To evaluate the significance of $\mathrm{m}^{2}$, a permutation procedure (Protest; Jackson, 1995) was used. To stabilize the estimated P-values, we used 10,000 randomizations (Jackson \& Somers, 1989).

NMDS, MRPP, IndVal, and PCA were calculated in PC$\operatorname{Ord}^{\circledR} 4.0$ (McCune \& Mefford, 1999). The analysis of variance was carried out in Statistica ${ }^{\mathrm{TM}}$ 7.0. The procrustes statistic was calculated in PROTEST ${ }^{\circledR}$ (Jackson, 1995). The statistical significance level adopted for all analysis was 0.05.

\section{Results}

\section{Fish assemblage}

A total of 4,768 individuals were caught, which were ascribed to 25 species of 6 orders and 10 families (Table 2). Regarding the urbanization gradient (see Table 1 ), the highest number of species was captured in the Jacutinga Stream (20 species; 1,709 individuals), followed by Pinheirinho (19 species; 1700 individuals) and Panambi streams (18 species; 1359 individuals; Table 2). The largest number of non-native species (Oreochromis niloticus, Poecilia reticulata, Tilapia rendalli, and Xiphophorus helleri) was observed in streams with high urbanization level (Table 2).

\section{Composition and structure of the fish assemblages}

The NMDS summarized the composition and structure of the fish assemblages and separated the studied streams (Fig. 2). After 38 iterations, the stability criterion was met with a final stress of 13.93 (Monte Carlo test: $\mathrm{p}<0.00422$ ) for the 2dimensional solution. The proportion of variance represented by each axis, based on the $\mathrm{r}^{2}$ between distance in the ordination space and distance in the original space, was 0.73 for the axis 1 and 0.16 for the axis 2 , summing up 0.89 .

The distribution of points along the axes 1 and 2 (Fig. 2a) suggests that the composition and structure of the fish assemblages were highly affected by spatial changes along the urbanization gradient. We found significant differences in the composition and structure of fish assemblages among streams (MRPP; $A=0.173 ; \mathrm{p}<0.001$ ). These differences can be clearly observed in the distribution of the average values of the axes 1 and 2 (Figs. 2b-c), showing that urbanization affects the composition and structure of the stream ichthyofauna.

The urbanization gradient was characterized by different sets of indicator species (IndVal; Table 3). Astyanax aff. bockmanni, Crenicichla britskii, Gymnotus pantanal, Hoplias sp. 3, and Phalloceros harpagos were significant indicators in the Jacutinga Stream, which has low urbanization. Astyanax aff. fasciatus, Astyanax aff. paranae, Heptapterus mustelinus, and Trichomycterus sp. were significant indicators in the Pinheirinho Stream. Hypostomus ancistroides, Rhamdia quelen and, the non-native species $X$. helleri were significant indicators in the Panambi Stream, which was considered as the most affected by urbanization.

\section{Abiotic variables}

Mean values of physical, chemical, and morphometric variables of the streams are presented in Table 4. According to the MANOVA, the effect of streams was significant $\left(\mathrm{F}_{30 ; 92}\right.$ $=6.75 ; \mathrm{p}<0.001$ ). Significant spatial differences were found in conductivity, $\mathrm{pH}$, dissolved oxygen, total phosphorus, width, discharge, depth, and silt (Table 4).

The principal component analysis produced a matrix of physical and chemical variables and a matrix of morphometric variables. In the analyses of both matrices, two axes were retained for interpretation. In the PCA based on physical and chemical variables (cumulative explained variance $=49.92 \%$; 
Table 2. List of species and number of individuals recorded along the urbanization gradient in urban streams (Jac, Jacutinga; Pin, Pinheirinho; Pan, Panambi) in the city of Toledo, State of Paraná, southern Brazil, from December 2007 to December 2008. * Non-native species; Tol = Tolerance (T = tolerant; S = sensitive), following Bozzetti \& Schulz (2004), Pinto \& Araújo (2007), and Casatti et al. (2009, 2012).

\begin{tabular}{|c|c|c|c|c|c|}
\hline Species/streams & Jac & Pin & Pan & Tol & Voucher Number \\
\hline \multicolumn{6}{|l|}{ Characiformes } \\
\hline \multicolumn{6}{|l|}{ Crenuchidae } \\
\hline Characidium aff. zebra Eigenmann, 1909 & 78 & 75 & 4 & $\mathrm{~S}$ & NUP 8537 \\
\hline \multicolumn{6}{|l|}{ Characidae } \\
\hline \multicolumn{6}{|l|}{ Incertae sedis } \\
\hline Astyanax altiparanae Garutti \& Britski, 2000 & 0 & 23 & 17 & $\mathrm{~S}$ & NUP 8556 \\
\hline Astyanax aff. bockmanni Vari \& Castro, 2007 & 116 & 0 & 20 & $\mathrm{~S}$ & NUP 8529 \\
\hline Astyanax aff. fasciatus (Cuvier, 1819) & 19 & 456 & 42 & $\mathrm{~S}$ & NUP 8548 \\
\hline Astyanax aff. paranae Eigenmann, 1914 & 8 & 732 & 32 & $\mathrm{~S}$ & NUP 8540 \\
\hline \multicolumn{6}{|l|}{ Erythrinidae } \\
\hline Hoplias sp. 1 & 1 & 1 & 0 & & NUP 8528 \\
\hline Hoplias sp. 2 & 4 & 1 & 2 & & NUP 8510 \\
\hline Hoplias sp. 3 & 30 & 1 & 2 & & NUP 8509 \\
\hline \multicolumn{6}{|l|}{ Siluriformes } \\
\hline \multicolumn{6}{|l|}{ Trichomycteridae } \\
\hline Trichomycterus sp. & 31 & 263 & 3 & & NUP 8520 \\
\hline \multicolumn{6}{|l|}{ Loricariidae } \\
\hline Ancistrus sp. & 1 & 0 & 0 & & NUP 8532 \\
\hline Hypostomus ancistroides (Ihering, 1911) & 83 & 22 & 142 & $\mathrm{~T}$ & NUP 8511 \\
\hline \multicolumn{6}{|l|}{ Heptapteridae } \\
\hline Heptapterus mustelinus (Valenciennes, 1835) & 0 & 12 & 0 & $\mathrm{~S}$ & NUP 8547 \\
\hline Rhamdia quelen (Quoy \& Gaimard, 1824) & 8 & 0 & 257 & $\mathrm{~T}$ & NUP 8563 \\
\hline \multicolumn{6}{|l|}{ Gymnotiformes } \\
\hline \multicolumn{6}{|l|}{ Gymnotidae } \\
\hline Gymnotus pantanal Fernandes, Albert, Daniel-Silva, Lopes, Crampton \& Almeida-Toledo, 2005 & 73 & 9 & 3 & $\mathrm{~T}$ & NUP 9290 \\
\hline Gymnotus sylvius Albert \& Fernandes-Matioli, 1999 & 28 & 27 & 196 & $\mathrm{~T}$ & NUP 9291 \\
\hline \multicolumn{6}{|l|}{ Cyprinodontiformes } \\
\hline \multicolumn{6}{|l|}{ Poeciliidae } \\
\hline Phalloceros harpagos Lucinda, 2008 & 1079 & 51 & 565 & $\mathrm{~T}$ & NUP 8561 \\
\hline Poecilia reticulata Peters, $1859 *$ & 4 & 9 & 1 & $\mathrm{~T}$ & NUP 8527 \\
\hline Xiphophorus helleri Heckel, 1848 * & 0 & 0 & 9 & & NUP 8560 \\
\hline \multicolumn{6}{|l|}{ Synbranchiformes } \\
\hline \multicolumn{6}{|l|}{ Synbranchidae } \\
\hline Synbranchus marmoratus Bloch, 1795 & 18 & 5 & 16 & $\mathrm{~T}$ & NUP 8566 \\
\hline \multicolumn{6}{|l|}{ Perciformes } \\
\hline \multicolumn{6}{|l|}{ Cichlidae } \\
\hline Cichlasoma paranaense Kullander, 1983 & 5 & 2 & 18 & $\mathrm{~T}$ & NUP 8541 \\
\hline Crenicichla britskii Kullander, 1982 & 120 & 0 & 0 & $\mathrm{~S}$ & NUP 8531 \\
\hline Crenicichla niederleinii (Holmberg, 1891) & 1 & 0 & 0 & $\mathrm{~S}$ & --- \\
\hline Geophagus brasiliensis (Quoy \& Gaimard, 1824) & 0 & 1 & 0 & $\mathrm{~T}$ & NUP 8545 \\
\hline Oreochromis niloticus (Linnaeus, 1758) * & 2 & 9 & 30 & $\mathrm{~T}$ & NUP 8544 \\
\hline Tilapia rendalli (Boulenger, 1897) * & 0 & 1 & 0 & $\mathrm{~T}$ & --- \\
\hline Total number of individuals & 1,709 & 1,7 & 1,359 & & \\
\hline Total richness & 20 & 19 & 18 & & \\
\hline
\end{tabular}

Fig. 3a), the axis 1 (eigenvalue: 2.43 ; \% of variance: $30.34 \%$ ) was the most important. Total phosphorus and conductivity (eigenvectors: 0.58 and 0.56 , respectively) were positively correlated with the axis 1 , whereas the variable dissolved oxygen (eigenvector: -0.32 ) was negatively correlated with the axis 1 (Fig. 3a). These variables were responsible for the separation of sites along the urbanization gradient, according to physical and chemical variables.

In the PCA based on morphometric variables (cumulative explained variance $=73.02 \%$; Fig. $3 b$ ), the axis 1 (eigenvalue: 4.14; \% of variance: $51.77 \%$ ) was also the most important (Fig. 3b), although less evidently. This PCA showed that the streams were relatively homogeneous in terms of morphometric variables. Width (eigenvector: 0.41), sand
(0.38), and discharge (0.38) were positively correlated with the axis 1 , whereas silt (eigenvector: -0.36 ) was negatively correlated with the axis 1 (Fig. 3b).

Abiotic variables and their relationship with fish assemblages

The axes (ordinations) with abiotic variables were compared with the NMDS axis (ordinations), which summarized the composition and structure of the fish assemblages. The distribution of the three streams on the first two axes was associated only with physical and chemical variables. The association with physical and chemical variables on the composition and structure of fish assemblages was significant $\left(\right.$ PROTEST; $\left.\mathrm{m}^{2}=0.94 ; \mathrm{p}=0.040\right)$. The variables associated with spatial changes were phosphorus, conductivity, and dissolved 

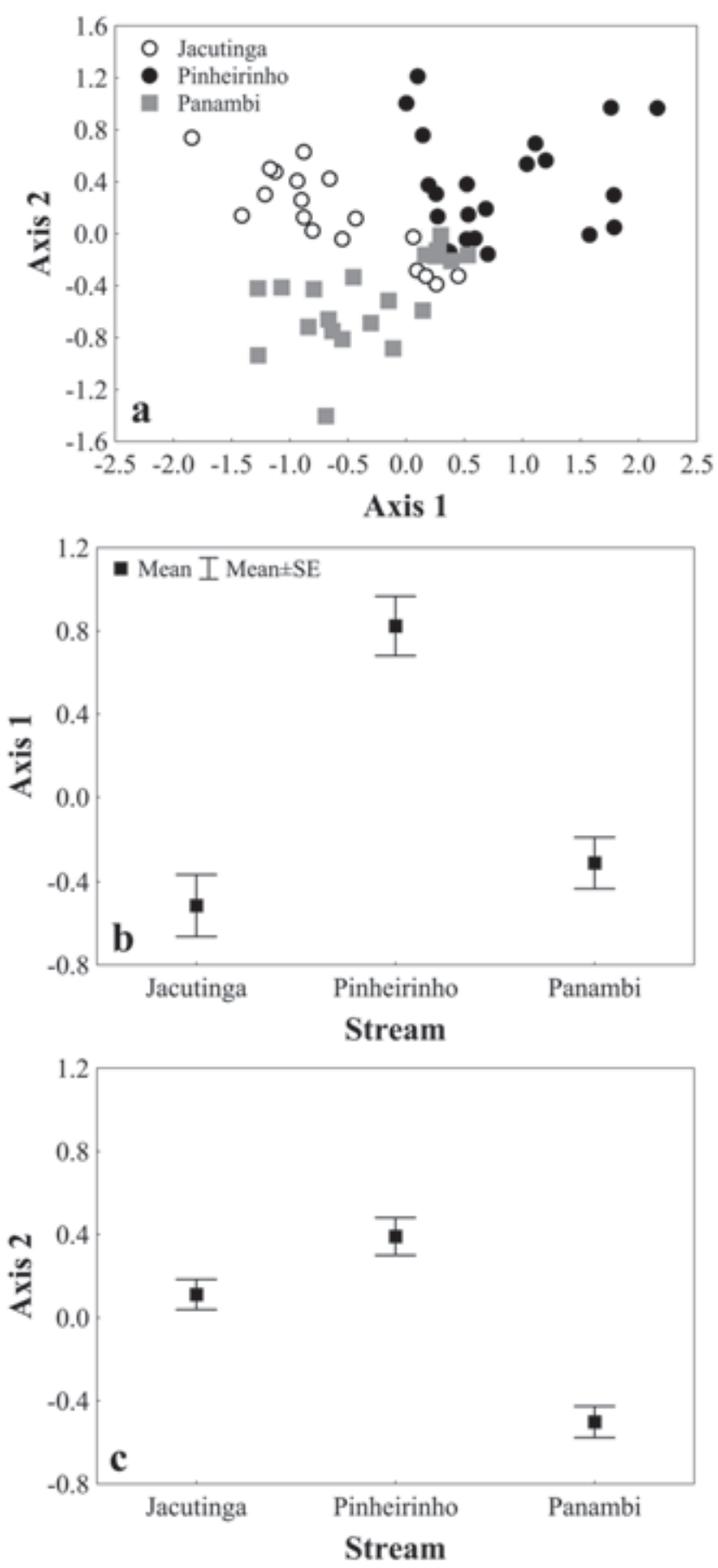

Fig. 2. Non-metric multidimensional scaling (NMDS) ordination of the fish assemblages in the streams Jacutinga, Pinheirinho, and Panambi (a) Axis 1 x Axis 2, and average values ( \pm standard error) of axis scores in the NMDS ordination for streams, (b) axis 1 and (c) axis 2.

oxygen. However, morphometric variables were not significant (PROTEST; $\mathrm{m}^{2}=0.94 ; \mathrm{p}=0.053$ ) corroborating the lack of association between morphometric variables and the distribution of fish assemblage.
Table 3. Summary of the indicator species analysis: relative abundance, relative frequency, and indicator value for each stream (Jac, Jacutinga; Pin, Pinheirinho; Pan, Panambi) studied in the city of Toledo, State of Paraná, southern Brazil. Only species with significant values are shown. Values in boldface indicate significant indicator values $(\mathrm{p}<0.05$, Monte Carlo test).

\begin{tabular}{lccccccccc}
\hline \multirow{1}{*}{\multicolumn{1}{c}{ Species }} & \multicolumn{3}{c}{$\begin{array}{c}\text { Relative } \\
\text { abundance }\end{array}$} & \multicolumn{3}{c}{$\begin{array}{c}\text { Relative } \\
\text { frequency }\end{array}$} & \multicolumn{3}{c}{$\begin{array}{c}\text { Indicator } \\
\text { value }\end{array}$} \\
\cline { 2 - 11 } & Jac & Pin & Pan & Jac & Pin & Pan & Jac & Pin & Pan \\
\hline Astyanax aff. bockmanni & 85 & 0 & 15 & 57 & 0 & 10 & $\mathbf{4 9}$ & 0 & 1 \\
A. aff. fasciatus & 4 & 88 & 8 & 14 & 57 & 43 & 1 & $\mathbf{5 0}$ & 3 \\
A. aff. paranae & 1 & 95 & 4 & 19 & 90 & 57 & 0 & $\mathbf{8 6}$ & 2 \\
Crenicichla britskii & 100 & 0 & 0 & 29 & 0 & 0 & $\mathbf{2 9}$ & 0 & 0 \\
Gymnotus pantanal & 86 & 11 & 4 & 90 & 29 & 14 & $\mathbf{7 8}$ & 3 & 1 \\
Hypostomus ancistroides & 34 & 9 & 57 & 76 & 33 & 90 & 26 & 3 & $\mathbf{5 2}$ \\
Heptapterus mustelinus & 0 & 100 & 0 & 0 & 19 & 0 & 0 & $\mathbf{1 9}$ & 0 \\
Hoplias sp. 3 & 91 & 3 & 6 & 48 & 5 & 10 & $\mathbf{4 3}$ & 0 & 1 \\
Phalloceros harpagos & 64 & 3 & 33 & 81 & 43 & 76 & $\mathbf{5 2}$ & 1 & 25 \\
Rhamdia quelen & 3 & 0 & 97 & 19 & 0 & 90 & 1 & 0 & $\mathbf{8 8}$ \\
Trichomycterus sp. & 10 & 89 & 1 & 52 & 43 & 10 & 5 & $\mathbf{3 8}$ & 0 \\
Xiphophorus helleri & 0 & 0 & 100 & 0 & 0 & 24 & 0 & 0 & $\mathbf{2 4}$ \\
\hline
\end{tabular}

\section{Discussion}

Many factors affect the structure, composition, distribution, and functioning of ecological assemblages: primary production, habitat use, resource limitation, interspecific interactions, climate, morphometric variables, and zoogeographical factors (Gido \& Jackson, 2010; Olden et al., 2010). Local processes (limnological and structural characteristics of the habitat and intra- and interspecific interactions) have been suggested as the main structuring factors of fish assemblages in different environments (Wang et al., 2006; Johnson et al., 2007). However, in urban watersheds, environmental variables affect the structure of fish assemblages at multiple spatial scales; the structure of the fish assemblage results from in-stream conditions, and the effect of catchment conditions on fish is expressed both directly and indirectly through its influence on in-stream factors (Cunico et al., 2012). In the present study, the association of the fish assemblages with electric conductivity, total phosphorus, and dissolved oxygen along an urbanization gradient evidenced the effects of chemical changes caused by urban organic effluents and surface runoff. Aquatic environments in urban regions have higher concentration of nutrients (phosphorus and nitrogen), due to inefficient sewage treatment and illegal effluent discharge (Paul \& Meyer, 2008; Alexandre et al., 2010). Similarly, residues created by human activities have diffuse effects on water bodies and are associated with surface runoff in catchment areas. Nutrient concentration in watersheds with impervious surface above $5 \%$ often exceeds that of other watersheds during both baseflow and stormflow (Schoonover et al., 2005). According to Alberti (2005), high nutrient concentration, which is frequently observed in urban drainage areas, creates unsuitable conditions for some fish species. Our results corroborate these observations, as streams in more urbanized 
Table 4. Summary of physical, chemical and morphometric variables (mean \pm SD) measured in urban streams (Jac, Jacutinga; Pin, Pinheirinho; Pan, Panambi) in the city of Toledo, State of Paraná, southern Brazil, based on samples collected from December 2007 to December 2008 (BOD: biochemical oxygen demand; COD: chemical oxygen demand). Results of the analysis of variance for each variable (values in italic, $\mathrm{H}$ - Kruskal-Wallis) are also presented. Values in boldface and letters in superscript indicate significant spatial differences along the urbanization gradient (Tukey test and Dunn test; $\mathrm{p}<0.05$ ). F; $\mathrm{H}=\mathrm{F}$ and $\mathrm{H}$ statistic; p = significant level. *Data rank transformed.

\begin{tabular}{|c|c|c|c|c|c|}
\hline Variable & Jacutinga & Pinheirinho & Panambi & F; H & $\mathrm{p}$ \\
\hline Conductivity $\left(\mu \mathrm{S} . \mathrm{cm}^{-1}\right)$ & $31.27 \pm 18.60^{\mathrm{a}}$ & $55.55 \pm 16.36^{\mathrm{b}}$ & $110.33 \pm 61.84^{\mathrm{C}}$ & 29.39 & $<0.01^{*}$ \\
\hline $\mathrm{pH}$ & $6.38 \pm 0.35^{\mathrm{a}}$ & $6.58 \pm 0.38^{\mathrm{a}}$ & $6.92 \pm 0.34^{\mathrm{b}}$ & 12.16 & $<0.01$ \\
\hline Water temperature $\left({ }^{\circ} \mathrm{C}\right)$ & $21.36 \pm 2.62$ & $20.74 \pm 1.77$ & $21.95 \pm 2.25$ & 1.53 & 0.22 \\
\hline Dissolved oxygen (mg. $\mathrm{l}^{-1}$ ) & $5.27 \pm 2.49^{\mathrm{a}}$ & $7.15 \pm 0.66^{\mathrm{b}}$ & $5.53 \pm 1.23^{c}$ & 18.59 & $<0.01$ \\
\hline Total nitrogen $\left(\mathrm{N}, \mu \mathrm{g} . \mathrm{l}^{-1}\right)$ & $0.68 \pm 0.66$ & $0.59 \pm 0.54$ & $0.78 \pm 0.62$ & 0.51 & 0.60 \\
\hline Total phosphorus $\left(\mathrm{P}, \mu \mathrm{g} . \mathrm{l}^{-1}\right)$ & $0.06 \pm 0.05^{\mathrm{a}}$ & $0.05 \pm 0.05^{\mathrm{a}}$ & $0.27 \pm 0.33^{b}$ & 9.66 & $<0.01 *$ \\
\hline $\mathrm{BOD}\left(\mathrm{mg} \cdot \mathrm{l}^{-1} \mathrm{O}_{2}\right)$ & $3.52 \pm 2.57$ & $8.43 \pm 7.53$ & $6.43 \pm 6.50$ & 3.06 & $0.05^{*}$ \\
\hline $\mathrm{COD}\left(\mathrm{mg} . \mathrm{l}^{-1} \mathrm{O}_{2}\right)$ & $11.06 \pm 6.81$ & $9.68 \pm 6.74$ & $15.14 \pm 8.42$ & 3.12 & 0.05 \\
\hline Width (m) & $2.21 \pm 0.78^{\mathrm{a}}$ & $2.27 \pm 0.45^{\mathrm{a}}$ & $3.72 \pm 0.86^{b}$ & 24.57 & $<0.01$ \\
\hline Water velocity $\left(\mathrm{m} . \mathrm{s}^{-1}\right)$ & $0.36 \pm 0.15$ & $0.44 \pm 0.18$ & $0.40 \pm 0.17$ & 1.26 & 0.29 \\
\hline Discharge $\left(\mathrm{m}^{3} \cdot \mathrm{s}^{-1}\right)$ & $0.15 \pm 0.16^{\mathrm{a}}$ & $0.20 \pm 0.15^{\mathrm{a}}$ & $0.37 \pm 0.23^{b}$ & 8.51 & $<0.01$ \\
\hline Depth (m) & $0.17 \pm 0.10^{\mathrm{a}}$ & $0.20 \pm 0.10^{\mathrm{b}}$ & $0.25 \pm 0.05^{c}$ & 11.75 & $<0.01$ \\
\hline Clay (g.kg-1) & $33.08 \pm 17.26$ & $24.39 \pm 6.63$ & $25.97 \pm 7.32$ & 1.66 & 0.43 \\
\hline Silt (g.kg-1 & $15.30 \pm 8.38^{\mathrm{a}}$ & $17.26 \pm 6.82^{\mathrm{b}}$ & $11.70 \pm 3.55^{\mathrm{c}}$ & 8.71 & 0.01 \\
\hline Sand (g.kg $\left.{ }^{-1}\right)$ & $48.45 \pm 28.20$ & $58.34 \pm 12.07$ & $62.34 \pm 7.82$ & 1.56 & 0.46 \\
\hline
\end{tabular}

areas had lower species richness, higher number of tolerant species, and higher occurrence of non-native species.

We found some potential indicator species. The high abundance and frequency of Poecilia reticulata, $R$. quelen, Heptapterus mustelinus, and Hypostomus ancistroides in the most urbanized areas show that these species may be potential indicators of urbanization. The families Poeciliidae, Heptapteridae, and Loricariidae are indicators of stream quality, because of their tolerance to habitat variations and impacted environments (Kennard et al., 2005; Vieira \& Shibatta, 2007; Winemiller et al., 2008). The species Poecilia reticulata, $R$. quelen, Heptapterus mustelinus, and Hypostomus ancistroides are resistant to changes in water quality, specially high concentration of phosphorus, low dissolved oxygen, and low depth (Cunico et al., 2006; Vieira \& Shibatta, 2007). The occurrence of some invasive species is strongly related to habitat degradation; they replace native species (Casatti et al., 2006, 2012). Altered conditions in urban streams may facilitate colonization by non-native species (Boët et al., 1999; McKinney, 2006; Paul \& Meyer, 2008). Boët et al. (1999) reported that the urbanization of Paris resulted in the introduction of 19 non-native species and the disappearance of seven out of 27 native fish species from the Seine River. In addition, aquarium trade has been a frequent cause of fish species introduction in urban environments. Non-native ornamental species of the genera Poecilia and Xiphophorus are commonly found in urban aquatic environments in South America (Cunico et al., 2009). In addition, fish diversity and abundance decrease along the longitudinal gradient, whereas the relative abundance of tolerant species, which are usually non-native, increases with urbanization (Boët et al., 1999; Gafny et al., 2000; Onorato et al., 2000).

The release of industrial residues and urban wastes into surface waters is a major threat to biodiversity in urban aquatic environments. In Indian and Chinese rivers, impacts of pollution on fish assemblages have been reported (Natarajan, 1989; Dudgeon, 2000). Provenzano et al. (2003) studied the Lake Valencia Basin in Venezuela and showed that urban and industrial pollutants resulted in poorer stream fish assemblages and probably in the extinction of at least one endemic species. Moreover, excessive loads of organic matter increase biological oxygen demand, phosphorus and nitrogen concentrations, and reduce dissolved oxygen in the water column of streams, what may lead to massive fish mortality (Boët et al., 1999; Winemiller et al., 2008). In addition, other land use regimes may have also significant impacts (e.g., agriand aquaculture, strongly active in the studied streams).

The total phosphorus concentration in an aquatic environment may be used to assess the impact of human activities. The total phosphorus concentration increased along the studied urbanization gradient; the highest values were recorded in the streams that were most affected by urbanization. According to Paul \& Meyer (2001), high nutrient concentration in urban areas, mainly phosphorus, are caused by an increase in particles associated with this element present in sewage and by the leaching of impervious surfaces, resulting in reduction in oxygen levels and changing the composition and structure of the ichthyofauna.

Anthropogenic activities, such as urbanization, agriculture, and aquaculture, may alter the ichthyofauna of streams. Hence, urban planning is essential to avoid stream sedimentation, altered hydrology, and large loads of nutrients and organic matter. A low increase (5\% in the streams Pinheirinho and Panambi) in the urbanization level has changed the composition and structure of fish assemblages, due to changes in conductivity and concentrations of dissolved oxygen and total phosphorus. Spatial changes were reflected in the presence of tolerant and non-native species, which 

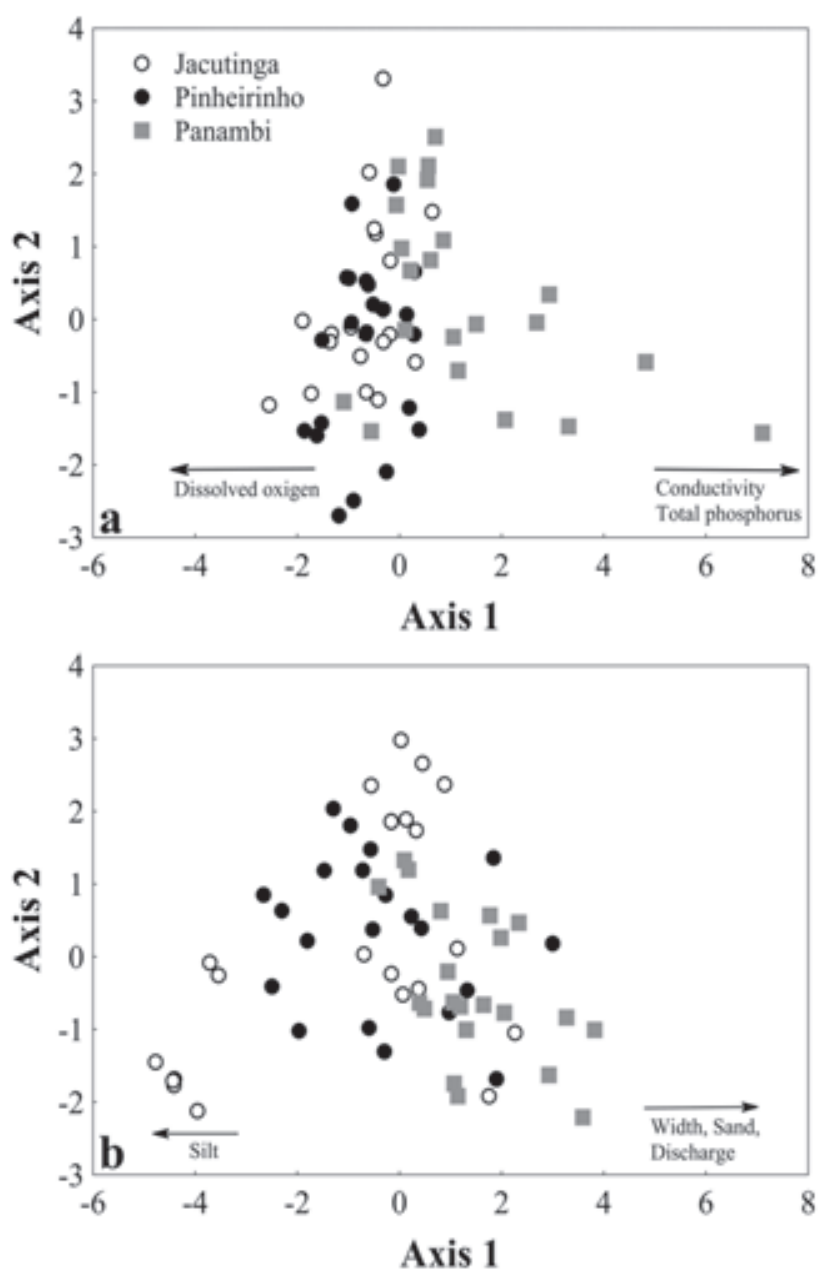

Fig. 3. Principal component analysis (PCA; Axis $1 \mathrm{x}$ Axis 2) of the urbanization gradient (streams Jacutinga, Pinheirinho, and Panambi) of physical and chemical variables (a) and morphometric variables (b) of urban streams in the city of Toledo, State of Paraná, southern Brazil, based on data collected from December 2007 to December 2008.

may easily invade more urbanized sites. Thus, management aimed at reducing runoff, decreasing impervious areas, and reducing point source pollution should be implemented, in order to preserve the native ichthyofauna.

\section{Acknowledgements}

We thank Gerpel/Unioeste (Grupo de Pesquisas em Recursos Pesqueiros e Limnologia) for providing us with the logistics for collecting and analyzing samples, and the electrofishing staff of Gerpel (Tiago Debona, Vinicius V. dos Santos, Anderson L. Maciel, Vitor A. Frana, Pedro R. L. da Silva, Tatiane M. Gogola, Eveline Arsego, Carlos H. Orsi and Cleomar Fernandez) for helping us in the fieldwork. CNPq (Conselho Nacional de Desenvolvimento Científico e Tecnológico) gave G. Baumgartner a research grant (process 477049/2007-9).

\section{Literature Cited}

Agostinho, A. A., F. M. Pelicice \& L. C. Gomes. 2008. Dams and the fish fauna of the Neotropical region: impacts and management related to diversity and fisheries. Brazilian Journal of Biology, 68: 1119-1132.

Alberti, M., D. Booth, K. Hill, B. Coburn, C. Avolio, S. Coe \& D. Spirandelli. 2007. The impact of urban patterns on aquatic ecosystems: An empirical analysis in Puget lowland sub-basins. Landscape and Urban Planning, 80: 345-361.

Alberti, M. 2005. The effects of urban patterns on ecosystem function. International Regional Science Review, 28: 168-192.

Alexandre, C. V., K. E. Esteves \& M. A. M. Moura e Mello. 2010. Analysis of fish communities along a rural-urban gradient in a neotropical stream (Piracicaba River Basin, São Paulo, Brazil). Hydrobiologia, 641: 97-114.

APHA, 2005. Standard Methods for the Examination of Water and Wastewater. American Public Health Association, 20 ${ }^{\text {th }}$ edition, Washington D.C.

AVMA, 2001. Panel on euthanasia. Report of the AVMA panel on euthanasia. Journal of the American Veterinary Medical Association, 218: 669-696.

Boët, P., J. Belliard, R. Berrebi-Dit-ThomaS \& E. Tales. 1999. Multiple human impacts by the city of Paris on fish communities in the Seine river basin, France. Hydrobiologia, 410: 59-68.

Bozzetti, M. \& U. H. Schulz. 2004. An index of biotic integrity based on fish assemblages for subtropical streams in southern Brazil. Hydrobiologia, 529: 133-144.

Camara, G., R. C. M. Souza \& G. J. Freitasum. 1996. SPRING: Integrating remote ensingand GIS by object-oriented data modelling. Computers \& Graphics, 20: 395-403.

Casatti, L., F. Langeani, A. M. Silva \& R. M. C. Castro. 2006. Stream fish, water and habitat quality in a pasture dominated basin, southeastern Brazil. Brazilian Journal of Biology, 66: 681-696.

Casatti, L., C. P. Ferreira \& F. Langeani. 2009. A fish-based biotic integrity index for assessment of lowland streams in southeastern Brazil. Hydrobiologia, 623: 173-189.

Casatti, L., F. B. Teresa, T. Gonçalves-Souza, E. Bessa, A. R. Manzotti, C. S. Gonçalves \& J. O. Zeni. 2012. From forests to cattail: how does the riparian zone influence stream fish? Neotropical Ichthyology, 10: 205-214.

Conover, W. J. \& R. L. Iman. 1981. Rank transformations as a bridge between parametric and nonparametric statistics. The American Statistics, 35: 124-128.

Cunico, A. M., A. A. Agostinho \& J. D. Latini. 2006. Influência da urbanização sobre as assembléias de peixes em três córregos de Maringá, Paraná (Influence of urbanization upon fish assemblages in three streams of Maringá, Paraná). Revista Brasileira de Zoologia, 23: 1101-1110.

Cunico, A. M., W. J. Graça, A. A. Agostinho, W. M. Domingues \& J. D. Latini. 2009. Fish, Maringá Urban Streams, Pirapó river drainage, upper Paraná river basin, Paraná State, Brazil. Check List, 5: 273-280.

Cunico, A. M., E. A. Ferreira, A. A. Agostinho, A. C. Beaumord \& R. Fernandes. 2012. The effects of local and regional environmental factors on the structure of fish assemblages in the Pirapó Basin, Southern Brazil. Landscape and Urban Planning, 105: 336-344.

Dudgeon, D. 2000. The ecology of tropical Asian rivers and streams in relation to biodiversity conservation. Annual Review of Ecology Systematics, 31: 239-263. 
Dufrêne, M. \& P. Legendre. 1997. Species assemblages and Indicator Species: the need for a flexible asymmetrical approach. Ecological Monographs, 67: 345-366.

Embrapa. 1997. Manual de métodos de análise de solo (Manual methods of soil analysis). Rio de Janeiro, Editora Europa, 212p.

Eschmeyer, W. N. (Ed.). 2012. Catalog of Fishes. California Academy of Sciences. (http://research.calacademy.org/research/ ichthyology/catalog/fishcatmain.asp). Electronic version accessed 02 February 2012.

Esteves, K. E. \& J. Lobón-Cerviá. 2001. Composition and trophic structure of a fish community of a clear water Atlantic rainforest stream in southeastern Brazil. Environmental Biology of Fishes, 62: 429-440.

Fialho, A. P., L. G. Oliveira, F. L. Tejerina-Garro \& B. Mérona. 2008. Fish-habitat relationship in a tropical river under anthropogenic influences. Hydrobiologia, 598: 315-324.

Gafny, S., M. Goren \& A. Gasith. 2000. Habitat condition and fish assemblage structure in a coastal Mediterranean stream (Yargon, Israel) receiving domestic effluent. Hydrobiologia, 422/423: 319-330.

Graça, W. J. \& C. S. Pavanelli. 2007. Peixes da planície de inundação do alto rio Paraná e áreas adjacentes (Fishes of the Paraná river floodplain and surrounding areas). Maringá, Eduem, 241p.

Gower, J. C. 1971. A general coefficient of similarity and some of its properties. Biometrics, 27: 857-874.

Gower, J. C. 1975. Generalized Procrustes Analysis. Psychometrika, 40: 33-51.

Gubiani, É. A., V. S. Daga, V. A. Frana \& W. J. Graça. 2010. Fish, Toledo urban stream, São Francisco drainage basin, upper Paraná River. Check List, 6: 45-48.

Gido, K. B. \& D. A. Jackson. 2010. Community Ecology of Stream Fishes: Concepts, Approaches, and Techniques. Bethesda, Maryland, American Fisheries Society, Symposium 73, 664p.

Hauer, F. R. \& G. A. Lamberti. 2007. Methods in stream ecology ( $2^{\text {nd }}$ ed.).Oxford, Elsevier, 896p.

Infante, D. M., J. D. Allan, S. Linke \& R. H. Norris. 2009. Relationship of fish and macroinvertebrate assemblages to environmental factors: implications for community concordance. Hydrobiologia, 623: 87-103.

Jackson, D. A. 1993. Stopping Rules in Principal Components Analysis: A comparison of heuristical and statistical approaches. Ecology, 74: 2204-2214.

Jackson, D. A. 1995. Bootstrapped principal component analysis: reply to Mehlman et al. Ecology, 76: 644-645.

Jackson, D. A. \& K. M. Somers. 1989. Are probability estimates from the permutation model of Mantel's test stable? Canadian Journal of Zoology, 67: 766-769.

Johnson, D. E. 1998. Applied Multivariate Methods for Data Analysis. Pacific Grove, Duxbury Press, 567p.

Johnson, R. K., M. T. Furse, D. Hering \& L. Sandin. 2007. Ecological relationships between stream communities and spatial scale: Implications for designing catchment-level monitoring programmes. Freshwater Biology, 52: 939-958.

Kennard, M. J., A. H. Arthington, B. J. Pusey \& B. D. Harch. 2005. Are alien fish reliable indicator of river health? Freshwater Biology, 50: 174-193.

Lee, T. R. 2000. Urban water management for better urban life in Latin America. Urban Water, 2: 71-78.

Maloney, K. O. \& D. E. Weller. 2010. Anthropogenic disturbance and streams: land use and land-use change affect stream ecosystems via multiple pathways. Freshwater Biology, 56: 611-626.
Matthews, W. J. 1998. Patterns in Freshwater Fish Ecology. New York, Chapman \& Hall, 756p.

McCune, B. \& J. B. Grace. 2002. Analysis of Ecological Communities. Oregon, USA, MjM Software, Gleneden Beach, 304p.

McCune, B. \& M. J. Mefford. 1999. Multivariate analysis on the PC-ORD system. Version 4. Oregon, USA, MjM Software, Gleneden Beach, 237p.

McKinney, M. L. 2006. Urbanization as a major cause of biotic homogenization. Biological Conservation, 127: 247-260.

Meyer, J. L., D. L. Strayer, J. B. Wallace, S. L. Eggert, G. S. Helfman \& N. E. Leonard. 2007. The contribution of headwater streams to biodiversity in river networks. Journal of the American Water Resources Association, 43: 86-103.

Montgomery, D. R. \& J. M. Buffington. 1998. Channel processes, classification, and response. Pp. 13-42. In: Naiman, R. \& R. Bilby (Eds.). River Ecology and Management. New York, Springer-Verlag, 683p.

Natarajan, A. V. 1989. Environmental impacts of Ganja basin development on Renepool and fisheries of the Ganga river system. Canadian Special Publication of Fisheries and Aquatic Sciences, 106: 545-560.

Olden, J. D., M. J. Kennard, F. Leprieur, P. A. Tedesco, K. O. Winemiller \& E. García-Berthou. 2010. Conservation biogeography of freshwater fishes: recent progress and future challenges. Diversity and Distributions, 16: 496-513.

Onorato, D., R. A. Angus \& K. R. Marion. 2000. Historical changes in the ichthyofaunal assemblages of the Upper Cahaba River in Alabama associated with extensive urban development in the watershed. Journal of Freshwater Ecology, 15: 47-63.

Ornellas, A. B. \& R. Coutinho. 1998. Spatial and temporal patterns of distribution and abundance of a tropical fish assemblage in a seasonal Sargassum bed, Cabo Frio Island, Brazil. Journal of Fish Biology, 53: 198-208.

Paul, M. J. \& J. L. Meyer. 2008. Streams in the urban landscape. Pp. 207-231. In: Marzluff, J. M., E. Shulenberger, W. Endlicher, M. Alberti, G. Bradley, C. Ryan, U. Simon, \& C. Zumbrunnen (Eds.). Urban ecology: An international perspective on the interaction between humans and nature. New York, Springer, 807p.

Paul, M. J. \& J. L. Meyer. 2001. Streams in the urban landscape. Annual Review of Ecology and Systematics, 32: 333-365.

Peres-Neto, P. R. \& D. A. Jackson. 2001. How well do multivariate data sets match? The robustness and flexibility of a Procrustean superimposition approach over the Mantel test. Oecologia, 129: $169-178$.

Pinto, B. C. T. \& F. G. Araújo. 2004. Assessing of Biotic Integrity of the Fish Community in a Heavily Impacted Segment of a Tropical River in Brazil. Brazilian Archives of Biology and Technology, 50: 489-502.

Pool, T. K., J. D. Olden, J. B. Whittier \& C. P. Paukert. 2010. Environmental drivers of fish functional diversity and composition in the Lower Colorado River Basin. Canadian Journal of Fisheries and Aquatic Sciences, 67: 1791-1807.

Provenzano, F. R., S. A. Schaefer, J. N. Baskin \& R. Royer-Leon. 2003. New, possibly extinct lithogenine loricariid (Siluriformes, Loricariidae) from Northern Venezuela. Copeia, 2003: 562-575.

Quinn, G. P. \& M. J. Keough. 2002. Experimental design and data analysis for biologists. Cambridge, UK Cambridge University Press, 738p.

Reis, R. E., S. O. Kullander \& C. J. Ferraris Jr. (Orgs.). 2003. Check List of the Freshwater Fishes of South and Central America. Porto Alegre, Edipucrs, 729p. 
Rohlf, F. J. \& D. E. Slice. 1990. Extensions of the Procrustes method for the optimal superimposition of landmarks. Systematic Zoology, 39: 40-59.

Scheiner, S. M. \& J. Gurevitch. 1993. Design and analysis of ecological experiments. New York, Chapman \& Hall, 445p.

Schindler, D. E. 2007. Fish extinctions and ecosystem functioning in tropical ecosystems. Proceedings of the National Academy of Sciences, 104: 5707-5708.

Schlosser, I. J. 1990. Environmental variation, life history attributes, and community structure in stream fish: implications for environmental management and assessment. Environmental Management, 14: 621-628.

Schlosser, I. J. 1991. Stream fish ecology: a landscape perspective. Bioscience, 41: 704-712.

Schoonover, J. E., B. G. Lockaby \& S. Pan. 2005. Changes in chemical and physical properties of stream water across an urban-rural gradient in western Georgia. Urban Ecosystems, 8: 107-124.

Suderhsa. 2009. Bacias hidrográficas do Paraná. Superintendência de Desenvolvimento de Recursos Hídricos e Saneamento Ambiental (Paraná river basins. Superintendent of Water Resources Development and Environmental Sanitation). Available at: http://www.suderhsa.pr.gov.br/modules/conteudo/ conteudo.php?conteudo=80 Accessed 29 December 2009.

Strahler, A. N. 1957. Quantitative analysis of watershed geomorphology. Transactions-American Geophysical Union, 38: 913-920.

Vieira, D. B. \& O. A. Shibatta. 2007. Peixes como indicadores da qualidade ambiental do ribeirão Esperança, município de Londrina, Paraná, Brasil. Biota Neotropica, 7: 57-65.

Zar, J. H. 1999. Biostatistical Analysis. 4 ed. Rio de Janeiro, Editora Prentice-Hall do Brasil Ltda, 929p.

Zimmerman, G. M., H. Goetz \& P. W. Mielke. 1985. Use of an improved statistical method for group comparisons to study effects of prairie fire. Ecology, 66: 606-611.

Wang, L., P. W. Seelbach \& J. Lyons. 2006. Effects of levels of human disturbance on the influence of catchment, riparian, and reach-scale factors on fish assemblages. American Fisheries Society Symposium, 48: 199-219.

Winemiller, K. O., A. A. Agostinho \& E. P. Caramaschi. 2008. Fish ecology in tropical streams. Pp. 107-146. In: Dudgeon, D. (Ed.). Tropical streams ecology, San Diego, CA, Elsevier/Academic Press, 370p.

Submitted February 17, 2012

Accepted June 8, 2012

Published September 28, 2012 